\title{
Magnesium Insertion in Vanadium Oxides: A Structural Study
}

\author{
By Petr Novák
}

Paul Scherrer Institute, Electrochemistry Section, CH-5232 Villigen PSI, Switzerland

\author{
Valery Shklover and Reinhard Nesper \\ Institute of Crystallography and Petrography, and Laboratory for Inorganic Chemistry, \\ ETH-Zentrum, CH-8092 Zürich, Switzerland
}

Dedicated to Professor Dr. Wolf Vielstich on the occasion of his 70 th birthday

(Received July 7, 1993; accepted August 30, 1993)

\section{Magnesium battery / Vanadium oxides / $\mathbf{M g}^{2+}$ ion insertion / $X$-ray diffraction / Electrochemistry}

X-ray powder diffraction patterns of $\mathrm{V}_{2} \mathrm{O}_{5}$-related electrode materials $\left[\mathrm{V}_{2} \mathrm{O}_{5}, \mathrm{NaV}_{3} \mathrm{O}_{8}\right.$ and $\mathrm{Mg}\left(\mathrm{V}_{3} \mathrm{O}_{8}\right)_{2}$ ] as well as of poly(tetrafluoroethylene)-bonded composite electrodes, containing chemically and electrochemically inserted $\mathrm{Mg}^{2+}$, were analysed before and after $\mathrm{Mg}^{2+}$ insertion. Transmission electron microscopy and both wavelength and energy dispersive electron probe microanalysis were applied for the determination of the composition and structure of different types of microparticles found in the electrode mass.

Röntgen-Pulverdiffraktogramme einiger $\mathrm{V}_{2} \mathrm{O}_{5}$-verwandten $\mathrm{Mg}^{2+}$-einlagernden Elektrodenmaterialien $\left[\mathrm{V}_{2} \mathrm{O}_{5}, \mathrm{NaV}_{3} \mathrm{O}_{8}\right.$ und $\left.\mathrm{Mg}\left(\mathrm{V}_{3} \mathrm{O}_{8}\right)_{2}\right]$ sowie der Polytetrafluoroethylen-haltigen Verbundelektroden wurden vor und nach der chemischen sowie elektrochemischen Einlagerung von $\mathrm{Mg}^{2+}$ ausgewertet. Transmissions-Elektronenmikroskopie sowie wellenlängen- und energieaufgelöste Elektronen-Mikroprobenanalyse wurden für die $\mathrm{Be}$ stimmung von Zusammensetzung und Struktur der in der Elektrodenmasse gefundenen verschiedenen Mikroteilchen eingesetzt.

\section{Introduction}

High energy density rechargeable ion transfer batteries are currently under development in many laboratories. They consist of an alkali metal negative electrode, an aprotic (nonaqueous) electrolyte, and a positive insertion electrode. The merit of this concept is that the same number of cations 
generated at one of the electrodes is at the same time consumed at the opposite electrode. Thus, in contrast to customary batteries there is no need for comparatively large electrolyte volumes.

Due to its natural abundance, low equivalent weight, and low price, metallic magnesium might be an alternative to lithium or sodium in a future ion transfer battery [1 -4]. Unfortunately, the magnesium electrochemistry at ambient temperatures is far from being well understood, and only few compounds containing inserted magnesium ions have been mentioned in the literature [1 - 14].

We regard $\mathrm{V}_{2} \mathrm{O}_{5}$ and other related vanadium oxides as promising electroactive materials for the positive insertion electrode of a secondary Mg-battery [3, 4]. $\mathrm{Mg}^{2+}$ ions can be inserted in the oxide chemically or electrochemically. An overall scheme for the electrochemical reaction can be written as

$$
\mathrm{V}_{2} \mathrm{O}_{5}+x \mathrm{Mg}^{2+}+2 x \mathrm{e}^{-} \Leftrightarrow \mathrm{Mg}_{x} \mathrm{~V}_{2} \mathrm{O}_{5} .
$$

Electrochemical tests have shown that the insertion reactions are fairly reversible. The amount of $\mathrm{Mg}^{2+}$ inserted in $\mathrm{V}_{2} \mathrm{O}_{5}$ depends on the nature of the electrolyte, on the ratio between the amounts of $\mathrm{H}_{2} \mathrm{O}$ and $\mathrm{Mg}^{2+}$ in the solution as well as on the absolute amount of $\mathrm{H}_{2} \mathrm{O}$ in the electrolyte [3]. The highest coulombic capacities ${ }^{1}$, about $200 \mathrm{Ah} / \mathrm{kg}$, were reached on $\mathrm{V}_{2} \mathrm{O}_{5}$ (and $\left.\mathrm{V}_{6} \mathrm{O}_{13}\right)$ in acetonitrile solution containing $1 \mathrm{Mgg}\left(\mathrm{ClO}_{4}\right)_{2}+$ $1 M \mathrm{H}_{2} \mathrm{O}[3,15]$. The amount of $\mathrm{Mg}^{2+}$ inserted in $\mathrm{V}_{2} \mathrm{O}_{5}$ decreases with the decreasing amount of $\mathrm{H}_{2} \mathrm{O}$ in the solution and approaches about $20 \mathrm{Ah} /$ $\mathrm{kg}$ in fairly dry electrolytes [3].

In order to facilitate the $\mathrm{Mg}^{2+}$ insertion in the interlayer space of the oxide, we attempted to increase the distance between the $\mathrm{V}_{2} \mathrm{O}_{5}$ layers by introducing metal ions in the $\mathrm{V}_{2} \mathrm{O}_{5}$ lattice, forming, thus, vanadium bronzes. Indeed, several vanadium bronzes such as $\mathrm{NaV}_{3} \mathrm{O}_{8}$ and $\mathrm{Mg}\left(\mathrm{V}_{3} \mathrm{O}_{8}\right)_{2}$ show promising coulombic capacities of up to $110 \mathrm{Ah} / \mathrm{kg}$ in rigorously dry electrolytes [4].

Obviously, variations in the crystal structure of the insertion materials influence their ability to accommodate $\mathrm{Mg}^{2+}$ or other metal ions. The present work attempts to determine the structures of the $\mathrm{Mg}^{2+}$-inserted $\mathrm{V}_{2} \mathrm{O}_{5}$ as well as of the vanadium bronzes (which are both poorly crystalline). Efforts have been made to correlate the results of the crystallographic structural analysis of the vanadium bronzes with their electrochemical behaviour, with the aim of gaining information necessary for the future design and optimisation of the synthesis of bronzes with higher coulombic capacity.

${ }^{1}$ Coulombic capacity is defined as charge stored in $1 \mathrm{~kg}$ of the oxide and corresponds with the amount of $\mathrm{Mg}^{2+}$ inserted in the oxide. 
Table 1. Scheme of preparation of Mg-inserted vanadium oxides*.

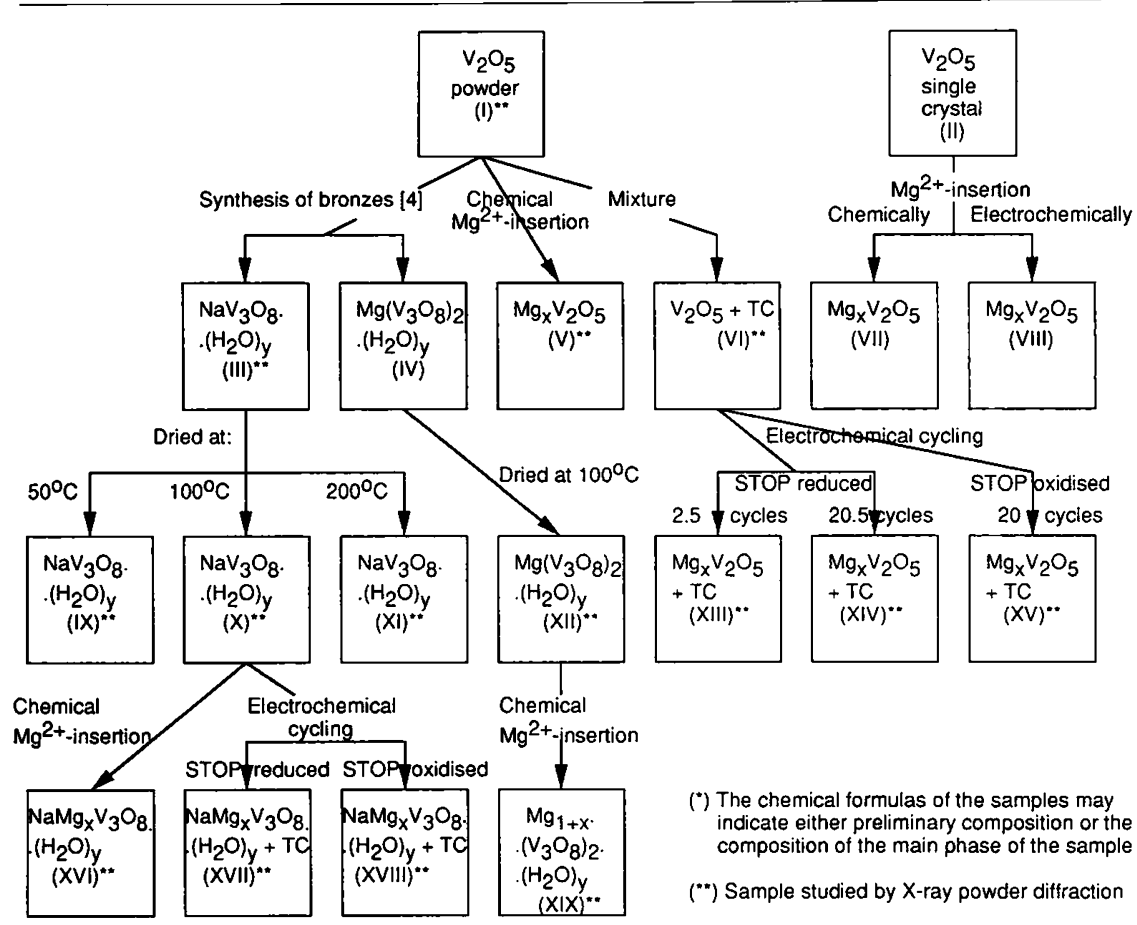

\section{Experimental}

\subsection{Materials}

As received $\mathrm{V}_{2} \mathrm{O}_{5}$ powder (I, Aldrich, 99.6+\%) and $\mathrm{V}_{2} \mathrm{O}_{5}$ single crystals ${ }^{2}$ (II) were used as starting materials for the experiments (Table 1). The bronzes, $\mathrm{NaV}_{3} \mathrm{O}_{8}$ and $\mathrm{Mg}\left(\mathrm{V}_{3} \mathrm{O}_{8}\right)_{2}$ were prepared as in [4]: an aqueous solution of $\mathrm{NaOH}$, or an aqueous suspension of $\mathrm{MgO}$, was stirred with a stoichiometric amount of $\mathrm{V}_{2} \mathrm{O}_{5}$ (I) at $\sim 50^{\circ} \mathrm{C}$ overnight. The orange-yellow colour of $\mathrm{V}_{2} \mathrm{O}_{5}$ turned gradually to red-brown under slow precipitation of the hydrated bronze, $\mathrm{NaV}_{3} \mathrm{O}_{8}\left(\mathrm{H}_{2} \mathrm{O}\right)_{y}$ (III) or $\mathrm{Mg}\left(\mathrm{V}_{3} \mathrm{O}_{8}\right)_{2}\left(\mathrm{H}_{2} \mathrm{O}\right)_{y}$ (IV). The latter was filtered, washed with $\mathrm{H}_{2} \mathrm{O}$, and vacuum-dried at room temperature for several days. After a mild grinding, the hydrated bronze was further dried under dynamic vacuum at 50,100 , or $200^{\circ} \mathrm{C}$ overnight (IX-XII, Table 1). Note, the formula $\left(\mathrm{H}_{2} \mathrm{O}\right)_{y}$ denotes an unknown, variable amount of bound water, including $y=0$.

${ }^{2}$ The $\mathrm{V}_{2} \mathrm{O}_{5}$ single crystals, a gift of Dr. K. Kato of the National Institute for Research in Inorganic Materials, Tsukuba, Japan, were prepared by Y. Uchida and E. Bannai from reagent grade $\mathrm{V}_{2} \mathrm{O}_{5}$ of $99.99 \%$ purity using the floating-zone technique in an image furnace [16]. Detailed results of investigations of $\mathrm{Mg}^{2+}$-inserted single crystals will be reported in a forthcoming paper. 


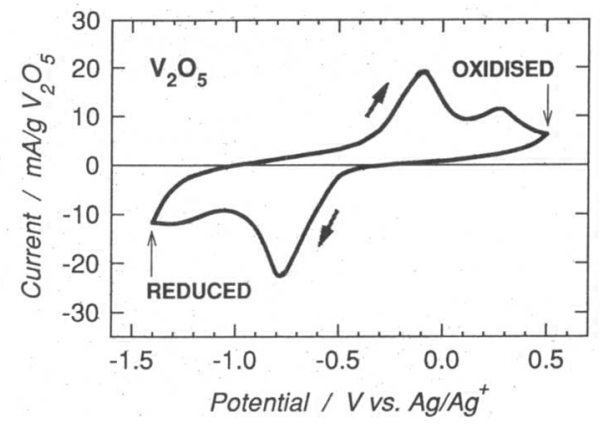

Fig. 1. Cyclic voltammogram (first cycle at $0.02 \mathrm{mV} / \mathrm{s}$ ) in the $1 \mathrm{M} \mathrm{Mg}\left(\mathrm{ClO}_{4}\right)_{2}+1 \mathrm{M}$ $\mathrm{H}_{2} \mathrm{O} / \mathrm{AN}$ electrolyte of a $\mathrm{V}_{2} \mathrm{O}_{5}$ electrode containing $50 \mathrm{wt}$ \% \% teflonised carbon (VI).

\subsection{Magnesium insertion}

The compounds $\mathrm{V}_{2} \mathrm{O}_{5}(\mathbf{I}, \mathbf{I I}), \mathrm{NaV}_{3} \mathrm{O}_{8}(\mathrm{IX}-\mathrm{XI})$ and $\mathrm{Mg}\left(\mathrm{V}_{3} \mathrm{O}_{8}\right)_{2}$ (XII) were screened for their ability to insert (excess) $\mathrm{Mg}^{2+}$ via chemical and electrochemical tests. Chemical insertion experiments involved placing either about $0.5 \mathrm{~g}$ of a powdery material or a $\mathrm{V}_{2} \mathrm{O}_{5}$ single crystal (II) in contact with excess $1 M$ dibutylmagnesium solution in heptane (Aldrich) under an Ar atmosphere, and allowing them to react under occasional stirring at room temperature for two months. The materials were then rinsed with heptane several times, dried, and examined for structural changes via $\mathrm{X}$-ray diffraction.

The electrochemical insertion of $\mathrm{Mg}^{2+}$ in $\mathrm{V}_{2} \mathrm{O}_{5}, \mathrm{NaV}_{3} \mathrm{O}_{8}$ and $\mathrm{Mg}\left(\mathrm{V}_{3} \mathrm{O}_{8}\right)_{2}$ was investigated using cyclic voltammetry at very slow potential sweep rates. To give the working electrodes sufficient electronic conductivity and mechanical stability, each of the electroactive materials was dry-mixed with an equal part of TC (Teflonised Carbon: 25 wt. \% PTFE +75 wt. \% acetylene black), and the mixture was spread by pressing on a current collector. To avoid oxygen and moisture contamination, all succeeding manipulations and measurements described below were performed either in an Ar-filled glove box in which the $\mathrm{H}_{2} \mathrm{O}$ and $\mathrm{O}_{2}$ levels were not permitted to exceed $5 \mathrm{ppm}$, or in hermetically sealed cells assembled in the glove box.

Electrochemical experiments were performed in two kinds of electrolytes: (i) at room temperature in acetonitrile (AN) solutions containing $1 \mathrm{M} \mathrm{Mg}\left(\mathrm{ClO}_{4}\right)_{2}$ and various amounts $(0.02 M-2.5 M)$ of $\mathrm{H}_{2} \mathrm{O}$, and (ii) at $80^{\circ} \mathrm{C}$ in room temperature molten salts. The salt melt contained 3 wt. $\% \mathrm{MgCl}_{2}, 56$ wt. $\% \mathrm{AlCl}_{3}$ and 41 wt. $\%$ 1-ethyl-3methylimidazolium chloride (EMIC). The experimental details have been described elsewhere $[3,4]$. Conventional glass cells with a free-hanging working electrode, as well as cells with working and counter electrodes pressed together with a spring were employed. (With the latter cells, better electrochemical performance at higher sweep rates, due to better electrical contact of the electroactive particles to the current collector, was observed.) The working electrodes had geometrical areas of $1.3-1.5 \mathrm{~cm}^{2}$ and contained $10-20 \mathrm{mg}$ of electroactive material. For the sake of comparison, the currents were normalised by the mass of the electroactive material. A magnesium counterelectrode and an $\mathrm{Ag} / \mathrm{Ag}^{+}$reference electrode were used in $\mathrm{AN}$ based solutions. In the salt melt, metallic aluminium served as the counterelectrode against which the potentials were also measured.

Electrochemically treated samples for X-ray powder diffraction measurements were prepared as follows: The working electrode was voltammetrically cycled, starting with a reduction sweep from the open circuit potential. Then, it was stabilised in the oxidised or reduced state at the appropriate potential (Fig. 1) overnight, removed from the cell, 
washed in dry deoxygenated acetonitrile overnight, and dried in the glove box atmosphere for several days. The electrode mass scraped from the current collector was loaded in a glass capillary which was sealed afterwards.

Electrochemical magnesium insertion experiments were performed also with $\mathrm{V}_{2} \mathrm{O}_{5}$ single crystals. The crystals were contacted by pressing them against a glassy carbon current collector, using the spring-loaded electrochemical cell described above. The electrolyte was $1 M \mathrm{Mg}\left(\mathrm{ClO}_{4}\right)_{2}+0.9 \mathrm{M} \mathrm{H}_{2} \mathrm{O}$ in $\mathrm{AN}$. In a typical experiment, the potential was sweeped at $0.5 \mu \mathrm{V} / \mathrm{s}$ from its open circuit value to $-1.4 \mathrm{~V}$ (vs. $\mathrm{Ag} / \mathrm{Ag}^{+}$). Then, the single crystal was reduced at $-1.4 \mathrm{~V}$ for 5 weeks. During this procedure, the orangeyellow colour of the $\mathrm{V}_{2} \mathrm{O}_{5}$ turned dark. The reduced crystal was washed with dry deoxygenated AN, dried in the glove box atmosphere, and analysed afterwards.

\subsection{Structural investigations}

X-ray powder diffraction patterns of samples I, III, V, VI and IX - XIX, sealed under an inert atmosphere in glass capillaries, were recorded using a STOE automatic powder diffractometer $\left(\mathrm{Cu} K_{\alpha}\right.$ radiation, $\mathrm{Ge}$ monochromator, small linear position sensitive detector, data collection in Debye mode, 150 steps within the $2 \Theta$ interval of $5-80^{\circ}, 1000 \mathrm{sec}$ per step). The patterns of the samples were indexed with the TREOR and LATCON programs.

A single crystal four-circle Nicolet diffractometer as well as a light microscope were used to study the electrochemically treated $\mathrm{V}_{2} \mathrm{O}_{5}$ sample VIII.

Transmission electron microscopy (TEM) studies of the samples XIII and XIV were performed on a Philips SM 30 ST transmission electron microscope equipped with a detector for energy dispersive X-ray spectrometry (EDX) and a STEM attachment, as well as with a Philips 500 scanning microscope with an EDX attachment.

Wavelength dispersive electron probe microanalysis (EPMA) [17] was applied for the determination of the Mg content in V, XII, XVI and XIX using a Cameca SX50 equipped with five spectrometers (accelerating voltage $20 \mathrm{kV}$, beam current $20 \mu \mathrm{A}$ ).

Solid state NMR spectra of the sample III were recorded with a Brucker AMX400 spectrometer equipped with a Wide-Bore-Magnet $\left(B_{0}=9.4\right.$ Tesla $)$ and a high-speed double-bearing MAS-probe.

\section{Results and discussion}

\subsection{Hydrated sodium vanadium bronzes III, IX, $X$ and $X I$}

To avoid a possible reaction of metallic magnesium with water, fairly dry electrolytes are preferred in a $\mathrm{Mg}$ battery. Because our preliminary electrochemical experiments have shown that the coulombic capacity of pure $\mathrm{V}_{2} \mathrm{O}_{5}$ significantly decreases with the decreasing amount of water in the electrolyte [3], vanadium bronzes of the $\mathrm{LiV}_{3} \mathrm{O}_{8}$ type were synthesised and tested for $\mathrm{Mg}^{2+}$ insertion. In contrast to the $\mathrm{V}_{2} \mathrm{O}_{5}$ case, the bronzes allow an electrochemical insertion of $\mathrm{Mg}^{2+}$ from a rigorously dry environment. As reported in [4], coulombic capacities of up to $110 \mathrm{Ah} / \mathrm{kg}$ were reached for the best samples of $\mathrm{NaV}_{3} \mathrm{O}_{8}$.

It follows from the comparison of coulombic capacities of the bronzes IX-XI dried at different temperatures that $\mathrm{NaV}_{3} \mathrm{O}_{8}$ dried at $200^{\circ} \mathrm{C}$ is 


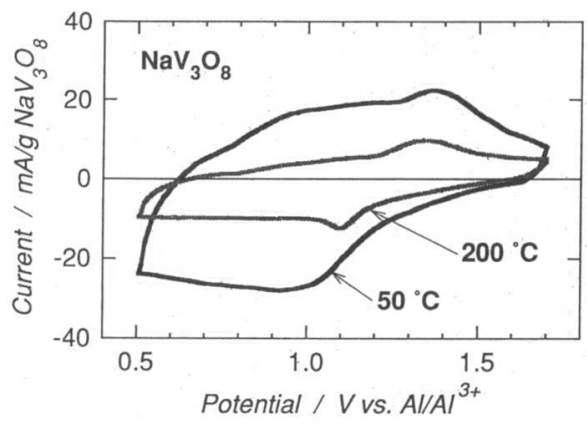

Fig. 2. Cyclic voltammograms (third cycles at $0.05 \mathrm{mV} / \mathrm{s}$ ) in the $\mathrm{MgCl}_{2} / \mathrm{AlCl}_{3} / \mathrm{EMIC}$ salt melt of $\mathrm{NaV}_{3} \mathrm{O}_{8}\left(\mathrm{H}_{2} \mathrm{O}\right)_{y}$ dried at $50^{\circ} \mathrm{C}(\mathbf{I X})$ and $200^{\circ} \mathrm{C}(\mathbf{X I})$. The electrode contained 50 wt. \% teflonised carbon.

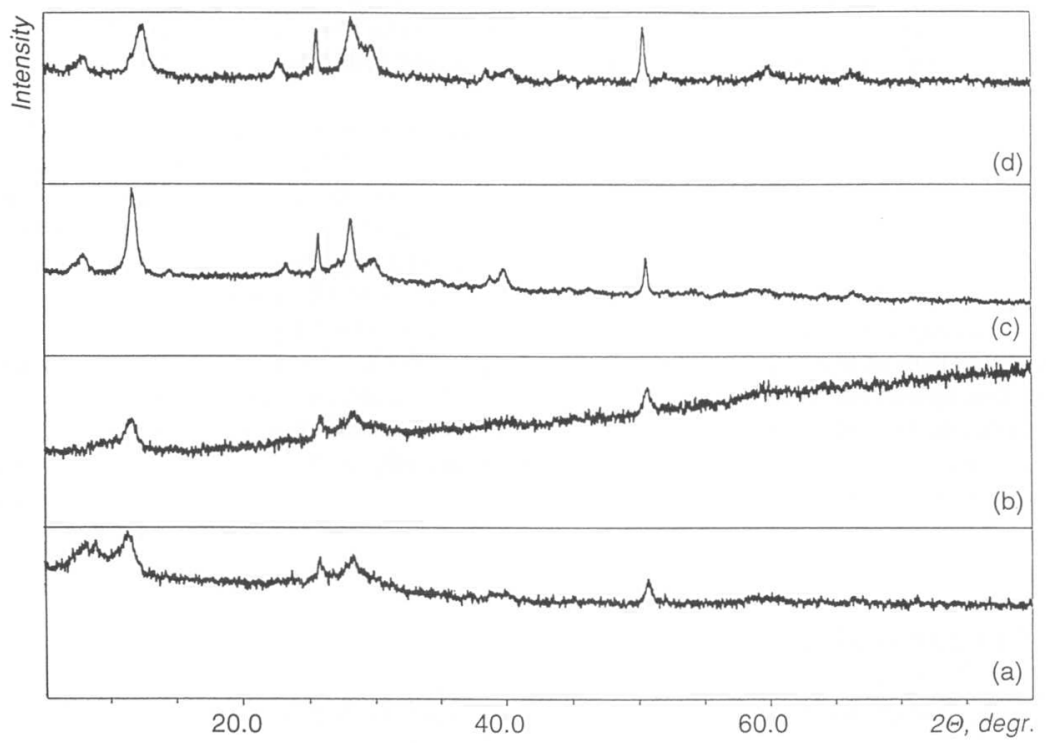

Fig. 3. X-ray powder diffraction patterns of (a) the bronze $\mathrm{NaV}_{3} \mathrm{O}_{8}\left(\mathrm{H}_{2} \mathrm{O}\right)_{y}$ (III), and of the products of its drying at (b) $50^{\circ} \mathrm{C}(\mathbf{I X}),(\mathrm{c}) 100^{\circ} \mathrm{C}$ (X) and (d) $200^{\circ} \mathrm{C}$ (XI).

electrochemically much less active than the bronzes dried at $\leq 100^{\circ} \mathrm{C}$. (There is no significant variance between the coulombic capacities of the 50 and $100^{\circ} \mathrm{C}$ samples.) This effect is illustrated in Fig. 2.

$\mathrm{X}$-ray diffraction patterns of the (poorly crystalline) bronze $\mathrm{NaV}_{3} \mathrm{O}_{8}\left(\mathrm{H}_{2} \mathrm{O}\right)_{y}$ (III) and the products IX, $\mathbf{X}$ and $\mathbf{X I}$ of drying of III at 50, 100 and $200^{\circ} \mathrm{C}$ are similar. The patterns have four common basic peaks (found at $2 \Theta=11.31^{\circ}, 25.84^{\circ}, 28.31^{\circ}$ and $50.73^{\circ}$ for III) (Fig. 3, 
Table 2. Positions ( $2 \Theta$, degree) and intensities $(I)$ of the peaks on the X-ray diffraction patterns of $\mathrm{NaV}_{3} \mathrm{O}_{8}\left(\mathrm{H}_{2} \mathrm{O}\right)_{y}$ (III) and the products of drying of III at $50^{\circ} \mathrm{C}(\mathrm{IX}), 100^{\circ} \mathrm{C}$ $(\mathbf{X})$, and $200^{\circ} \mathrm{C}(\mathbf{X I})$.

\begin{tabular}{|c|c|c|c|c|c|c|c|c|}
\hline \multicolumn{2}{|l|}{ III } & \multicolumn{2}{|l|}{ IX } & \multicolumn{2}{|l|}{$\mathbf{X}$} & \multicolumn{3}{|l|}{ XI } \\
\hline \multirow[t]{2}{*}{$2 \Theta$} & $I$ & $2 \Theta$ & $I$ & $2 \Theta$ & $I$ & $2 \Theta$ & $I$ & $h k l^{*}$ \\
\hline & & & & 7.30 & 13 & & & \\
\hline 8.13 & 40 & & & 8.05 & 25 & 8.03 & 35 & 100 \\
\hline \multirow[t]{2}{*}{8.90} & 52 & & & 8.24 & 20 & 8.23 & 35 & \\
\hline & & & & 11.42 & 44 & & & \\
\hline \multirow[t]{5}{*}{11.31} & 100 & 11.61 & 100 & 11.78 & 100 & 11.72 & 40 & 001 \\
\hline & & & & & & 12.55 & 88 & \\
\hline & & & & 14.64 & 10 & & & 200 \\
\hline & & & & & & 22.88 & 36 & \\
\hline & & & & 23.32 & 16 & & & \\
\hline \multirow[t]{2}{*}{25.84} & 79 & 25.87 & 85 & 25.82 & 51 & 25.73 & 82 & 110 \\
\hline & & & & 27.30 & 13 & & & \\
\hline \multirow[t]{10}{*}{28.31} & 76 & 28.34 & 67 & 28.30 & 58 & 28.28 & 87 & \\
\hline & & & & & & 28.52 & 74 & 111 \\
\hline & & & & & & 28.88 & 53 & \\
\hline & & & & 30.12 & 20 & 30.15 & 32 & -211 \\
\hline & & & & 34.86 & 14 & & & -103 \\
\hline & & & & 38.90 & 19 & 38.68 & 27 & -410 \\
\hline & & & & 39.85 & 28 & & & -303 \\
\hline & & & & 40.04 & 25 & & & \\
\hline & & & & & & 40.29 & 27 & \\
\hline & & & & & & 40.60 & 26 & \\
\hline \multirow[t]{4}{*}{50.73} & 50 & 50.70 & 98 & 50.66 & 47 & 50.50 & 100 & 204 \\
\hline & & & & & & 60.12 & 30 & \\
\hline & & & & & & 66.34 & 27 & -323 \\
\hline & & & & 66.47 & 10 & & & 305 \\
\hline
\end{tabular}

* Reflections indexed with the unit cell of barnesite $(a=12.17 \AA, b=3.602 \AA, c=$ $\left.7.78 \AA, \beta=95^{\prime \prime} 2^{\prime}, V=342.0 \AA^{3}[18]\right)$.

Table 2). The shift to larger $2 \Theta$ values in the series III $\rightarrow$ IX $\rightarrow \mathbf{X} \rightarrow \mathbf{X I}$ and the splitting (samples $\mathbf{X}$ and $\mathbf{X I}$ ) of the first peak (at $2 \Theta=11.31^{\circ}$ in III), and the approximate conservation of the positions of the three other basic peaks are worthy of attention. The single crystal data published for $\mathrm{NaV}_{3} \mathrm{O}_{8}\left(\mathrm{H}_{2} \mathrm{O}\right)_{1.5}$ [18] (existing in nature as the mineral barnesite) were used for the indexing of the patterns of III and IX - XI. Minor changes of the two unit cell parameters $b$ and $c$, and a large successive decrease of the parameter $a$ accompanied with a successive decrease of the unit cell volume with the increasing drying temperature (transition III $\rightarrow \mathbf{I X} \rightarrow \mathbf{X} \rightarrow \mathbf{X I}$ ) were observed. (Note that a lattice constant variation within one phase was observed also for the $\varepsilon$-phase of $\mathrm{Li}_{x} \mathrm{~V}_{2} \mathrm{O}_{5}$ bronzes [19].)

One may suggest a layered character of the crystal structure of the phases III and IX $-\mathbf{X I}$, a conservation of the structure within the layers, 


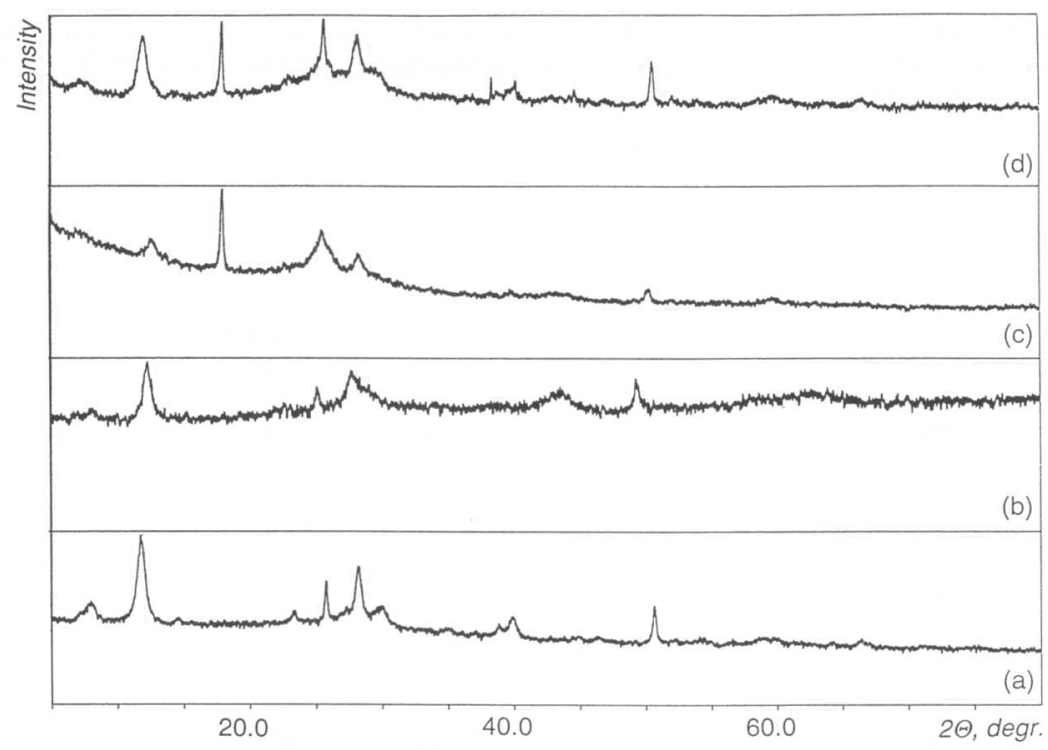

Fig. 4. X-ray powder diffraction patterns of (a) the bronze $\mathrm{NaV}_{3} \mathrm{O}_{8}\left(\mathrm{H}_{2} \mathrm{O}\right)_{y}$ dried at $100^{\circ} \mathrm{C}$ (X), and the products of (b) chemical (XVI) and (c, d) electrochemical (XVII, c and XVIII, d) $\mathrm{Mg}^{2+}$ insertion in $\mathbf{X}$.

and a decrease of the interlayer separation with water removal. The splitting of the first basic peak of $\mathbf{X}$ and $\mathbf{X I}$ may indicate a coexistence of two phases with different water content in the samples X and XI (Xa and Xb, XIa and XIb). Thus, the drying process probably proceeds in distinct steps, as, e.g., reported for the removal of excess water from the solid gel $\mathrm{V}_{2} \mathrm{O}_{5} \cdot y \mathrm{H}_{2} \mathrm{O}$ [20].

A similar abrupt change of the unit cell parameters, occurring during a water removal in the course of heating as observed for III and IX-XI, was reported earlier for the transition of hydrated sodium metavanadate: $\mathrm{NaVO}_{3}\left(\mathrm{H}_{2} \mathrm{O}\right)_{2} \rightarrow$ (transition phase) $\rightarrow \beta-\mathrm{NaVO}_{3}$ [21]. The closeness of the unit cell sizes of the studied hydrated sodium vanadium bronzes and the cited metavanadates is remarkable, but a ${ }^{51} \mathrm{~V}$ solid state NMR study of the sample III clearly indicated an octahedral coordination, and not the tetrahedral coordination of vanadium atoms characteristic for metavanadates $\left(\delta_{\text {iso }}=-533 \pm 10 \mathrm{ppm}, \delta=657 \pm 10 \mathrm{ppm}, \delta_{1}=\delta_{2}=-290 \pm\right.$ $10 \mathrm{ppm}, \delta_{3}=-947 \pm 10 \mathrm{ppm}$; for the interpretation of the solid state NMR data on vanadium compounds see [22]).

Combining the electrochemical and structural results, it seems to be reasonable to suggest that the hydrated bronze, $\mathrm{NaV}_{3} \mathrm{O}_{8}\left(\mathrm{H}_{2} \mathrm{O}\right)_{1.5}$, is electrochemically the most active constituent of the obtained Na-bronzes. Pronounced structural changes occur during the drying of this bronze above 
Table 3. Positions ( $2 \Theta$, degree) and intensities $(I)$ of the peaks on the X-ray diffraction patterns of the products of chemical (XVI) and electrochemical (XVII, XVIII) $\mathbf{M g}^{2+}$ insertion in the hydrated sodium vanadium bronze $(\mathbf{X})$.

\begin{tabular}{|c|c|c|c|c|c|}
\hline \multicolumn{2}{|l|}{ XVI } & \multicolumn{2}{|l|}{ XVII } & \multicolumn{2}{|l|}{ XVIII } \\
\hline $2 \Theta$ & $I$ & $2 \Theta$ & $I$ & $2 \Theta$ & $I$ \\
\hline 12.38 & 100 & 12.68 & 22 & $\begin{array}{l}12.11 \\
12.33\end{array}$ & $\begin{array}{l}78 \\
65\end{array}$ \\
\hline & & 18.11 & $100^{*}$ & 18.10 & $100^{*}$ \\
\hline 25.18 & 45 & 25.59 & 47 & 25.83 & 74 \\
\hline 27.76 & 55 & 28.33 & 30 & $\begin{array}{l}28.32 \\
38.51 \\
40.33\end{array}$ & $\begin{array}{l}59 \\
34 \\
31\end{array}$ \\
\hline 49.27 & 51 & 50.28 & 21 & 50.65 & 59 \\
\hline
\end{tabular}

* Peak 100 of triclinic PTFE [23] (from teflonised carbon).

$100^{\circ} \mathrm{C}$, and a new structure is formed which is able to accommodate significantly less $\mathrm{Mg}^{2+}$ than the bronze $\mathrm{NaV}_{3} \mathrm{O}_{8}\left(\mathrm{H}_{2} \mathrm{O}\right)_{1.5}$. Infrared spectroscopic investigations [4] have shown that water is expulsed, and dehydrated $\mathrm{NaV}_{3} \mathrm{O}_{8}$ is formed during the drying above $100^{\circ} \mathrm{C}$.

\subsection{Products of chemical (XVI) and electrochemical (XVII, XVIII) insertion of $\mathrm{Mg}^{2+}$ in the partially dehydrated sodium vanadium bronze $\mathrm{X}$}

The patterns of the poorly crystalline products XVI-XVIII of $\mathbf{M g}^{2+}$ insertion in $\mathbf{X}$ (Fig. 4, Table 3) can also be described using the four basic peaks, as the patterns of III and the drying products of III discussed above, and can be indexed with the unit cell of barnesite. A layered crystal structure can be proposed for the samples XVI-XVIII. The size of the unit cell (Xa: $344 \AA^{3}, \mathbf{X b}: 293 \AA^{3}$ ) decreases during both the chemical (XVI: $242 \AA^{3}$ ) and the electrochemical $\mathrm{Mg}^{2+}$ insertion (XVII: $227 \AA^{3}$ and XVIII: $262 \AA^{3}$ ). The electrochemically reduced product XVII has the smallest value of the unit cell volume. Note that recent electrochemical experiments [4] have shown that a significant amount of $\mathrm{Mg}^{2+}$ ions inserted in $\mathrm{NaV}_{3} \mathrm{O}_{8}\left(\mathrm{H}_{2} \mathrm{O}\right)_{y}$ during the first voltammetric cycle is irreversibly bonded in the crystal lattice of the bronze. Therefore, the electrochemically cycled, oxidised sample XVIII contained trapped $\mathrm{Mg}^{2+}$ ions.

The contraction of the unit cell volume of $\mathrm{NaV}_{3} \mathrm{O}_{8}\left(\mathrm{H}_{2} \mathrm{O}\right)_{y}$ during $\mathrm{Mg}^{2+}$ insertion is not surprising; a similar effect was already observed for cationintercalated $\mathrm{V}_{2} \mathrm{O}_{5}\left(\mathrm{H}_{2} \mathrm{O}\right)_{1.6}$ xerogels [24]. The electrostriction phenomenon can explain this behaviour: the intensity of the electrical field surrounding the cation leads to a decrease of the water molecule volume [24]. 


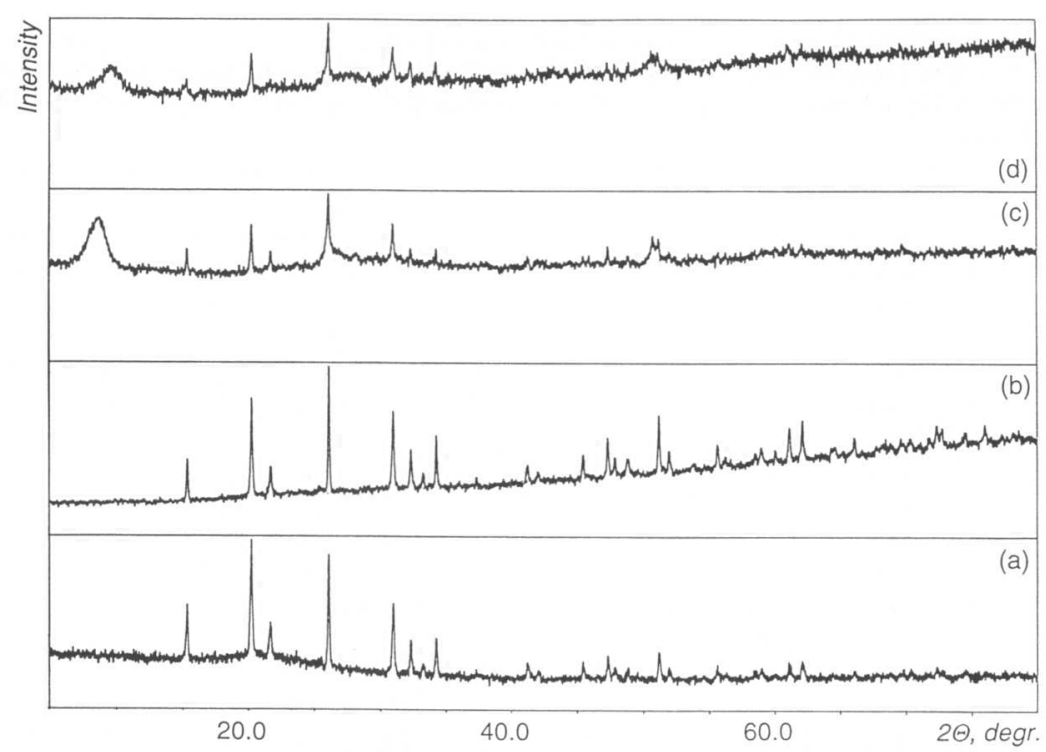

Fig. 5. X-ray powder diffraction patterns of (a) $\mathrm{V}_{2} \mathrm{O}_{5}$ (I), (b) $\mathrm{Mg}_{x} \mathrm{~V}_{2} \mathrm{O}_{5}$ (V), (c) the bronze $\mathrm{Mg}\left(\mathrm{V}_{3} \mathrm{O}_{8}\right)_{2}\left(\mathrm{H}_{2} \mathrm{O}\right)_{y}$ dried at $100^{\circ} \mathrm{C}(\mathrm{XII})$, and (d) the product $\mathrm{Mg}_{1+x}\left(\mathrm{~V}_{3} \mathrm{O}_{8}\right)_{2}\left(\mathrm{H}_{2} \mathrm{O}\right)_{y}(\mathrm{XIX})$ of chemical $\mathrm{Mg}^{2+}$ insertion in XII.

The $\mathrm{Mg}$ and $\mathrm{Na}$ contents, found by EPMA for different microparticles in the product XVI of chemical $\mathrm{Mg}^{2+}$ insertion in $\mathbf{X}$, varied in narrow intervals of $11.7-12.2$ at. $\%$ for $\mathrm{Mg}$, and of $5.4-5.8$ at. $\%$ for $\mathrm{Na}$.

\subsection{Products $\mathrm{V}$ and $\mathrm{XIX}$ of chemical $\mathrm{Mg}^{2+}$ insertion in $\mathrm{V}_{2} \mathrm{O}_{5}$ (I) and in the Mg bronze IV, XII}

The X-ray diffractograms of the samples I, V, XII and XIX are compared in Fig. 5; the positions of the diffraction peaks are given in Table 4. The patterns of the crystalline sample $\mathbf{I}$, and of the product $\mathbf{V}$ of the chemical $\mathrm{Mg}^{2+}$ insertion in $\mathrm{I}$ are very similar and represent $\mathrm{V}_{2} \mathrm{O}_{5}$. The $\mathrm{V}_{2} \mathrm{O}_{5}$ unit cell parameters calculated for $\mathbf{I}$ and $\mathbf{V}$, as well as for those peaks of XII and XIX, which can be indexed with the $\mathrm{V}_{2} \mathrm{O}_{5}$ unit cell, are compared in Table 5 with the lattice parameters of electrochemically prepared $\mathrm{Mg}_{0.2} \mathrm{~V}_{2} \mathrm{O}_{5}[10]$, and of $\mathrm{MgV}_{2} \mathrm{O}_{5}$ synthesised at $900^{\circ} \mathrm{C}$ [25]. In contrast to $\mathrm{Mg}_{0.2} \mathrm{~V}_{2} \mathrm{O}_{5}$, the distribution of peak intensities in $\mathbf{V}$ is very similar to those observed in $\mathbf{I}$, and could indicate an essentially smaller amount of inserted $\mathrm{Mg}^{2+}$ in $\mathbf{V}$ as compared to $\mathrm{Mg}_{0.2} \mathrm{~V}_{2} \mathrm{O}_{5}$. Indeed, the EPMA investigation showed a content of $1.0-1.2$ at. $\%$ of $\mathrm{Mg}$ in sample $\mathrm{V}$. (This is in agreement with the conclusion suggested in [3] that water molecules are essential for the $\mathrm{Mg}^{2+}$ insertion reaction of $\mathrm{V}_{2} \mathrm{O}_{5}$. Note that a dry environment is used for the chemical insertion of $\mathrm{Mg}^{2+}$ in the present work.) 
Table 4. Positions ( $2 \Theta$, degree) and intensities $(I)$ of the peaks on the X-ray diffraction patterns of the products $\mathrm{V}$ and XIX of chemical $\mathrm{Mg}^{2+}$ insertion in $\mathrm{V}_{2} \mathrm{O}_{5}$ (I) and $\mathrm{Mg}$ bronze (XII).

\begin{tabular}{|c|c|c|c|c|c|c|c|c|c|c|c|}
\hline \multicolumn{2}{|l|}{ I } & \multicolumn{3}{|l|}{$\mathbf{V}$} & \multicolumn{3}{|l|}{ XII } & \multicolumn{4}{|l|}{ XIX } \\
\hline $2 \Theta$ & $I$ & $2 \Theta_{\text {obs }}$ & $2 \Theta_{\mathrm{calc}}$ & $I$ & $2 \Theta_{\text {obs }}$ & $2 \Theta_{\text {calc }}$ & $I$ & $2 \Theta_{\text {obs }}$ & $2 \Theta_{\text {calc }}$ & $I$ & $h k l$ \\
\hline & & & & & 8.77 & & 65 & 9.70 & & 39 & ${ }^{*}$ \\
\hline 15.34 & 48 & 15.37 & 15.38 & 36 & 15.37 & 15.39 & 44 & 15.37 & 15.39 & 35 & 200 \\
\hline 20.25 & 96 & 20.29 & 20.28 & 79 & 20.29 & 20.30 & 79 & 20.30 & 20.29 & 66 & 001 \\
\hline 21.70 & 29 & 21.74 & 21.71 & 25 & 21.75 & 21.73 & 29 & & & & 101 \\
\hline 26.12 & 100 & 26.15 & 26.15 & 100 & 26.16 & 26.17 & 100 & 26.15 & 26.13 & 100 & 110 \\
\hline 31.02 & 62 & 31.03 & 31.04 & 64 & 31.03 & 31.06 & 55 & 31.01 & 31.06 & 62 & 400 \\
\hline 32.34 & 33 & 32.38 & 32.37 & 33 & 32.38 & 32.40 & 19 & 32.36 & 32.36 & 39 & 011 \\
\hline 34.28 & 35 & 34.31 & 34.31 & 44 & 34.33 & 34.34 & 28 & 34.30 & 34.30 & 41 & 310 \\
\hline 41.20 & 17 & 41.28 & 41.24 & 20 & & & & & & & 002 \\
\hline 45.44 & 17 & 45.49 & 45.46 & 23 & & & & & & & 411 \\
\hline 47.30 & 22 & 47.32 & 47.33 & 33 & 47.36 & 47.36 & 28 & & & & 600 \\
\hline & & & & & 50.78 & & 41 & 50.68 & & 33 & \\
\hline 51.17 & 26 & 51.23 & 51.22 & 49 & 51.26 & 51.26 & 35 & 51.16 & 51.16 & 35 & 020 \\
\hline 55.61 & 14 & 55.63 & 55.64 & 21 & & & & & & & 021 \\
\hline 61.05 & 16 & 61.13 & 61.11 & 29 & 60.98 & 61.15 & 36 & & & & 321 \\
\hline 62.05 & 16 & 62.11 & 62.09 & 33 & 62.13 & 62.13 & 31 & & & & 710 \\
\hline
\end{tabular}
phase.

* This reflection is contrary to the others, very broad and, thus, assigned to another

Table 5. Unit cell parameters of $\mathrm{V}_{2} \mathrm{O}_{5}(\mathbf{I}), \mathrm{V}_{2} \mathrm{O}_{5}$-related components of $\mathrm{V}$, XII and XIX, and vanadium pentoxide bronzes $\mathrm{Mg}_{0.2} \mathrm{~V}_{2} \mathrm{O}_{5}$ [10] and $\mathrm{MgV}_{2} \mathrm{O}_{5}$ [25].

\begin{tabular}{lllllll}
\hline & I & V & XII & XIX & $\mathrm{Mg}_{0.2} \mathrm{~V}_{2} \mathrm{O}_{5}$ & $\mathrm{MgV}_{2} \mathrm{O}_{5}$ \\
\hline$a(\AA)$ & $11.5204(9)$ & $11.513(2)$ & $11.508(1)$ & $11.508(8)$ & 11.42 & 11.019 \\
$b(\AA)$ & $3.5674(5)$ & $3.5640(6)$ & $3.5617(3)$ & $3.5679(6)$ & 3.552 & 3.696 \\
$c(\AA)$ & $4.3780(4)$ & $4.3745(8)$ & $4.370(2)$ & $4.372(2)$ & 4.468 & 9.965 \\
$V\left(\AA^{3}\right)$ & 179.93 & 179.50 & 179.12 & 179.50 & 181.2 & 405.8 \\
\hline
\end{tabular}

In sample XII, the EPMA study showed the presence of microparticles with distinctly different $\mathrm{Mg}^{2+}$ content, viz. yellow microcrystals with 0.14 at. $\%$ of $\mathrm{Mg}$, and brown microcrystals with $1.3-1.5$ at.\% of $\mathrm{Mg}$. The microparticles of the product XIX of the subsequent chemical insertion of $\mathrm{Mg}$ in XII contain 3.8-4.0 at.\% of Mg. Note that several phases related to $\mathrm{V}_{2} \mathrm{O}_{5}$, and a coexistence of different phases having the same Li content (multiphase domains) were reported for $\mathrm{Li}_{x} \mathrm{~V}_{2} \mathrm{O}_{5}$ bronzes [19].

$\mathrm{X}$-ray powder diffraction patterns of the poorly crystalline samples XII and XIX essentially differ from the patterns of $I$ and $V$. Some peaks on the patterns of XII and XIX, which are present also in I and V, are broadened 

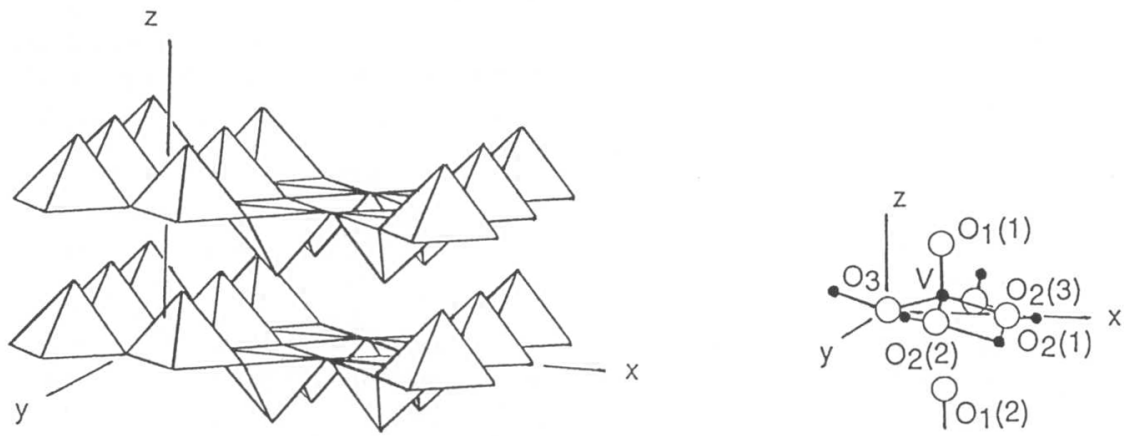

Fig. 6. Crystal structure of $\mathrm{V}_{2} \mathrm{O}_{5}$ [26].

in comparison with $\mathbf{I}$ and $\mathbf{V}$, but there are also some "new" peaks: (i) Strong and diffuse peaks at $2 \Theta=8.77^{\circ}$ (XII) and $9.70^{\circ}$ (XIX) which cannot be indexed with the unit cell of $\mathbf{I}$ or $\mathbf{V}$ (the first reflection 100 , which is actually absent in the measured pattern of $\mathbf{I}$, has $2 \Theta=7.67^{\circ}$ ); and (ii) new sharp peaks at $2 \Theta=50.78^{\circ}$ (XII) and $50.68^{\circ}$ (XIX) which are only slightly shifted from the $\mathrm{V}_{2} \mathrm{O}_{5} 020$ peak at $2 \Theta=51.23^{\circ}$ in the pattern of $\mathrm{V}$. Moreover, there is a hint of a small contraction of the $a$ separation of the $\mathrm{V}_{2} \mathrm{O}_{5}$ crystalline component in the series $\mathbf{I} \rightarrow \mathbf{V} \rightarrow$ XII $\rightarrow$ XIX. A slight shortening of the $a$ separation and a slight increase of the $c$ separation (corresponding to the interlayer separation in the structure of $\mathrm{V}_{2} \mathrm{O}_{5}$ [26], Fig. 6) is characteristic for a topotactic insertion in $\mathrm{V}_{2} \mathrm{O}_{5}$, see, e.g., the structural study of electrochemically formed $\mathrm{Mg}_{0.2} \mathrm{~V}_{2} \mathrm{O}_{5}$ bronze [10].

Besides the phase with the $\mathrm{V}_{2} \mathrm{O}_{5}$ structure, we believe that in the new phase(s) of the samples XII and XIX, a good ordering exists only in one direction, $b^{\prime}$. The length of this axis is slightly increased in comparison with the $b$ separation in I and $\mathbf{V}$. The value of $b^{\prime}$ is $3.59 \AA$ in XII, and $3.60 \AA$ in XIX (calculated under an assumption that the new sharp peak in patterns of XII and XIX is a 020 peak). The new phase(s) of XII and XIX are disordered in two other directions (i.e. in the $a^{\prime} c^{\prime}$ planes). Note that an earlier X-ray powder diffraction study of electroformed $\mathrm{Li}_{x} \mathrm{~V}_{2} \mathrm{O}_{5}$ bronzes showed a conservation of the $b$ separation of the $\mathrm{V}_{2} \mathrm{O}_{5}$ structure with an increased $\mathrm{Li}$ content parallel to more pronounced changes of the $a$ and $c$ separations [27].

\subsection{Products XIII - XV of electrochemical cycling of the $\mathrm{V}_{\mathbf{2}} \mathrm{O}_{\mathbf{5}}$ electrode $\mathrm{VI}$}

A cyclic voltammogram of the $\mathrm{V}_{2} \mathrm{O}_{5} / \mathrm{TC}$ electrode $\mathrm{VI}$ in an acetonitrilebased electrolyte is shown in Fig. 1. The X-ray diffraction patterns of the electrochemically cycled electrodes XIII $-\mathbf{X V}$ are compared with the pattern of a new electrode VI in Fig. 7 and in Table 6. The patterns of the new electrode VI and of the oxidised electrode $\mathbf{X V}$ are very close, and 


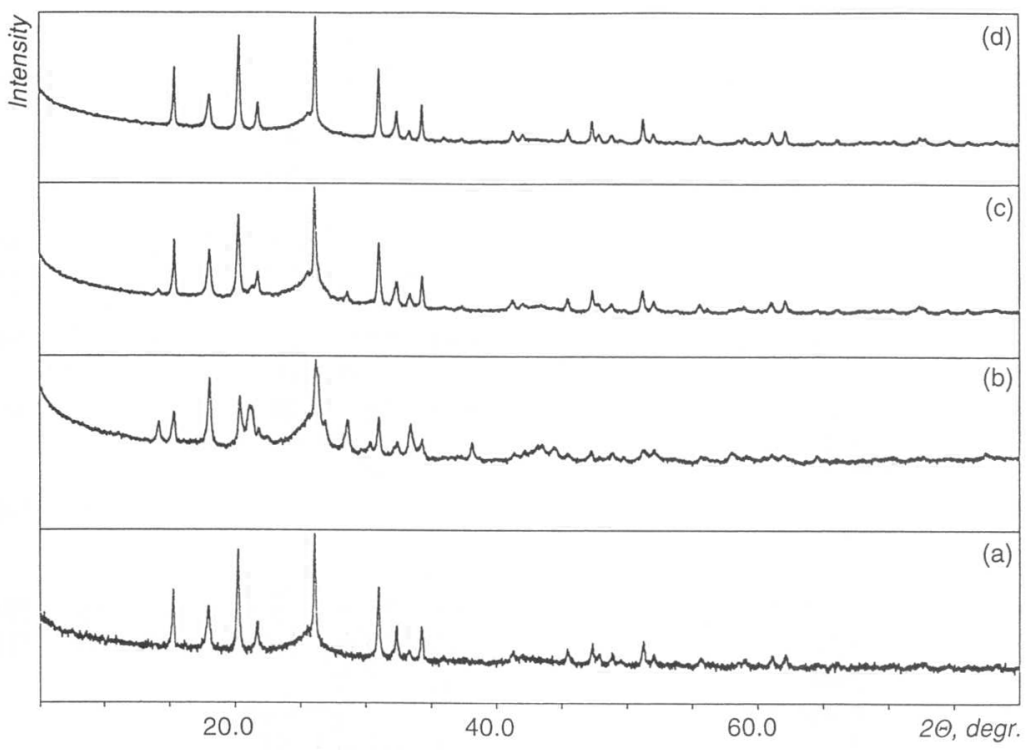

Fig. 7. X-ray powder diffraction patterns of (a) the electrode mass $\mathrm{V}_{2} \mathrm{O}_{5} / \mathrm{TC}$ (VI) and of the products of electrochemical $\mathrm{Mg}^{2+}$ insertion: (b) XIII (reduced electrode, after $2^{1} / 2$ cycles), (c) XIV (reduced electrode, after $20^{1} / 2$ cycles), and (d) XV (oxidised electrode, after 20 cycles).

represent a superposition of the pattern of $\mathrm{V}_{2} \mathrm{O}_{5}$ (or components with the unit cell close to $\mathrm{V}_{2} \mathrm{O}_{5}$, Table 7), and the mixture of crystalline PTFE and carbon black. The electrochemical reduction of the electrode VI leads to the appearance of some "new" peaks in the patterns of XIII and XIV (besides of the peaks of the $\mathrm{V}_{2} \mathrm{O}_{5}$ and TC components).

It can be speculated that the appearance of the $\mathrm{V}_{2} \mathrm{O}_{5}$ features in the reduced electrode means that a fraction of the $\mathrm{V}_{2} \mathrm{O}_{5}$ is not accessible for the electrochemical reduction. The reason might be a poor electrical contact of $\mathrm{V}_{2} \mathrm{O}_{5}$ particles to the current collector. This hypothesis is consistent with the fact that in the spring-loaded cell, where the working electrode is mechanically pressed against the current collector, significantly higher coulombic capacities (up to $230 \mathrm{Ah} / \mathrm{kg} \mathrm{V}_{2} \mathrm{O}_{5}$ ) were reached in comparison with the free-hanging electrodes (about $170 \mathrm{Ah} / \mathrm{kg} \mathrm{V}_{2} \mathrm{O}_{5}$ ).

But essentially different distribution of the peak intensities of the $\mathrm{V}_{2} \mathrm{O}_{5}$ component in sample XIII, in contrast to the distribution observed for the $\mathrm{V}_{2} \mathrm{O}_{5}$-containing new electrode $\mathrm{VI}$, might indicate the chemical composition $\mathrm{Mg}_{x} \mathrm{~V}_{2} \mathrm{O}_{5}$ of this component. The presence of $\mathrm{Mg}^{2+}$ in the $\mathrm{V}_{2} \mathrm{O}_{5}$ microcrystals found in the reduced electrode XIII was confirmed by EDX analysis. There is no pronounced change of the unit cell parameters of the $\mathrm{V}_{2} \mathrm{O}_{5}$ component during the transition from VI to XIII (Table 7). This 
Table 6. Positions ( $2 \Theta$, degree) and intensities $(I)$ of the peaks on the X-ray diffraction patterns of the products XIII $-\mathbf{X V}$ of electrochemical cycling of the $\mathrm{V}_{2} \mathrm{O}_{5}$-containing electrode mass VI.

\begin{tabular}{|c|c|c|c|c|c|c|c|c|c|c|c|}
\hline \multicolumn{2}{|l|}{ VI } & \multicolumn{3}{|l|}{ XIII* } & \multicolumn{3}{|l|}{ XIV* } & \multicolumn{4}{|l|}{$\mathbf{X V} \mathbf{V}^{*}$} \\
\hline $2 \Theta$ & $I$ & $2 \Theta_{\mathrm{obs}}$ & $2 \Theta_{\text {calc }}$ & $I$ & $2 \Theta_{\text {obs }}$ & $2 \Theta_{\text {calc }}$ & $I$ & $2 \Theta_{\text {obs }}$ & $2 \Theta_{\text {calc }}$ & $I$ & $h k l$ \\
\hline & & 14.25 & & 22 & 14.23 & & 5 & & & & \\
\hline 15.33 & 53 & 15.42 & 15.37 & 38 & 15.45 & 15.40 & 52 & 15.46 & 15.41 & 54 & 200 \\
\hline 18.02 & $79 * *$ & 18.17 & & $79 * *$ & 18.16 & & $43^{* *}$ & 18.17 & & $31^{* *}$ & \\
\hline \multirow[t]{2}{*}{20.26} & 91 & $\begin{array}{l}20.39 \\
21.10\end{array}$ & 20.36 & $\begin{array}{l}63 \\
56\end{array}$ & 20.35 & 20.34 & 75 & 20.38 & 20.35 & 82 & 001 \\
\hline & & 21.35 & & 41 & 21.36 & & 8 & & & & \\
\hline \multirow[t]{3}{*}{21.70} & 28 & 21.81 & 21.79 & 23 & 21.79 & 21.77 & 20 & 21.81 & 21.78 & 25 & 101 \\
\hline & & 22.03 & & 13 & & & & & & & \\
\hline & & 22.49 & & 12 & & & & & & & \\
\hline 25.79 & 16 & 25.87 & 25.61 & 34 & 25.68 & 25.61 & 21 & 25.94 & 25.62 & 16 & 201 \\
\hline \multirow[t]{5}{*}{26.12} & 100 & 26.22 & 26.20 & 100 & 26.21 & 26.18 & 100 & 26.24 & 26.23 & 100 & 110 \\
\hline & & 27.01 & & 34 & & & & & & & \\
\hline & & 28.40 & & 20 & & & & & & & \\
\hline & & 28.65 & & 34 & 28.67 & & 11 & & & & \\
\hline & & 30.36 & & 13 & & & & & & & \\
\hline 31.02 & 65 & 31.06 & 31.02 & 48 & 31.12 & 31.04 & 60 & 31.12 & 31.05 & 62 & 400 \\
\hline \multirow[t]{2}{*}{32.39} & 29 & 32.44 & 32.47 & 18 & 32.43 & 32.42 & 26 & 32.48 & 32.48 & 26 & 011 \\
\hline & & 33.48 & 33.41 & 37 & 33.44 & 33.37 & 16 & & & & 111 \\
\hline \multirow[t]{2}{*}{34.27} & 31 & 34.39 & 34.34 & 22 & 34.38 & 34.35 & 33 & 34.40 & 34.40 & 32 & 310 \\
\hline & & 38.18 & & 23 & & & & & & & \\
\hline \multirow[t]{4}{*}{41.33} & 11 & 41.44 & 41.41 & 11 & 41.33 & 41.35 & 12 & 41.36 & 41.37 & 12 & 002 \\
\hline & & 43.54 & & 17 & 43.56 & & 8 & & & & \\
\hline & & 43.76 & & 12 & & & & & & & \\
\hline & & 44.44 & & 17 & 44.43 & & 5 & & & & \\
\hline 45.42 & 13 & 45.46 & 45.52 & 10 & 45.50 & 45.54 & 13 & 45.57 & 45.59 & 13 & 411 \\
\hline 47.40 & 20 & 47.29 & & 12 & 47.42 & & 22 & 47.44 & & 20 & 600 \\
\hline 47.93 & 11 & 47.95 & 47.97 & 11 & 47.91 & 47.94 & 10 & & & & 302 \\
\hline 48.98 & 10 & 49.00 & 48.99 & 15 & & & & & & & 012 \\
\hline 51.27 & 22 & 51.35 & 51.34 & 18 & 51.28 & 51.27 & 22 & 51.31 & 51.39 & 22 & 002 \\
\hline \multirow[t]{2}{*}{52.09} & 13 & 52.14 & 52.00 & 19 & 52.10 & 52.09 & 13 & & & & 601 \\
\hline & & 58.05 & & 18 & & & & & & & \\
\hline 59.10 & 11 & & & & & & & & & & 412 \\
\hline 61.11 & 12 & & & & 61.19 & 61.18 & 11 & 61.21 & 61.27 & 11 & 321 \\
\hline 62.17 & 14 & & & & 62.19 & 62.20 & 13 & 62.20 & 62.26 & 13 & 710 \\
\hline
\end{tabular}

* See the discussion of not indexed reflections in the text.

** Peak of PTFE (from teflonised carbon).

indicates that $\mathrm{V}_{2} \mathrm{O}_{5}$ can be regarded as a three-dimensional framework host, rather than a two-dimensional one (as already suggested in studies of $\mathrm{Li}^{+}$insertion in $\left.\mathrm{V}_{2} \mathrm{O}_{5}[20,28]\right)$. 
Table 7. Unit cell parameters of $\mathrm{V}_{2} \mathrm{O}_{5}$-related components of the electrode mass $\mathrm{VI}$ and the products XIII $-\mathbf{X V}$ of its electrochemical cycling.

\begin{tabular}{lcccc}
\hline & VI & XIII & XIV & XV \\
\hline$a(\AA)$ & $11.533(6)$ & $11.520(7)$ & $11.495(3)$ & $11.489(3)$ \\
$b(\AA)$ & $3.562(1)$ & $3.556(2)$ & $3.561(1)$ & $3.553(1)$ \\
$c(\AA)$ & $4.376(4)$ & $4.357(2)$ & $4.363(2)$ & $4.3609(9)$ \\
$V\left(\AA^{3}\right)$ & 179.93 & 178.50 & 178.62 & 178.02 \\
\hline
\end{tabular}

The unit cell parameters of chemically (V) and electrochemically (XIII) formed $\mathrm{Mg}_{x} \mathrm{~V}_{2} \mathrm{O}_{5}$ are very close (cf. Tables 5 and 7). Thus, the products of $\mathrm{Mg}^{2+}$ insertion in $\mathrm{V}_{2} \mathrm{O}_{5}$ might be similar in both cases.

The new peaks appearing in the X-ray diffractogram of the $\mathrm{V}_{2} \mathrm{O}_{5} / \mathrm{TC}$ electrode reduced at $-1.4 \mathrm{~V}\left(\mathrm{vs} . \mathrm{Ag} / \mathrm{Ag}^{+}\right.$) after $2^{1} / 2$ voltammetric cycles (XIII) can be separated into two groups: (i) five peaks present also in the sample XIV reduced after $20^{1} / 2$ voltammetric cycles, and (ii) peaks present only in XIII (Table 6). These two groups of peaks have to belong to different phases (e.g. XIIIa and XIIIb), because, e.g., the strongest new peak in the pattern of XIII (at $2 \Theta=21.10^{\circ}$ ) is absent in the pattern of XIV. Thus, the reduced electrode XIII may consist of five phases: $\mathrm{V}_{2} \mathrm{O}_{5}$ (or $\mathrm{Mg}_{x} \mathrm{~V}_{2} \mathrm{O}_{5}$ ), carbon black, PTFE, XIIIa (which exists also in XIV), and XIIIb.

The amount of the phase XIIIb in the electrode obviously decreases during cycling as evidenced by the absence of corresponding peaks in the diffractogram of the electrode XIV reduced after $20^{1} / 2$ cycles. This behaviour is consistent with the known fact that $\mathrm{Mg}_{x} \mathrm{~V}_{2} \mathrm{O}_{5}$ exists in two phases - a stable orthorhombic $\alpha$ phase $(0<x<0.11)$ and a metastable $\zeta$ phase [6]. Note the XIIIa and XIIIb phases are absent in the oxidised, cycled electrode $\mathrm{XV}$, so they are products of reversible $\mathrm{V}_{2} \mathrm{O}_{5}$ reduction. The indexing of the XIIIb phase is ambiguous. One of the solutions is an orthorhombic unit cell $[a=17.69(1) \AA, b=13.003(4) \AA, c=3.360(2) \AA$, $\left.V=773 \AA^{3}\right]$ with one period equal to that observed in $\mathrm{MgV}_{2} \mathrm{O}_{5}$ and the unit cell volume four time larger as of $\mathrm{MgV}_{2} \mathrm{O}_{5}$. Also the unit cell of the phase XIIIa cannot be elucidated, because the indexing of the corresponding lines gives several solutions of comparable reliability. Thus, the electrochemical reduction of VI seems to lead to both (i) $\mathrm{Mg}^{2+}$ insertion in $\mathrm{V}_{2} \mathrm{O}_{5}$ with the conservation of the $\mathrm{V}_{2} \mathrm{O}_{5}$ structure, and (ii) formation of new $\mathrm{Mg}, \mathrm{V}$-containig phase(s) (XIIIa or XIIIa + XIIIb).

The TEM study of XIII confirmed the presence of microcrystals with the unit cell close to $\mathrm{V}_{2} \mathrm{O}_{5}$ in electrochemically reduced samples. There were obtained, besides the common $\mathrm{V}_{2} \mathrm{O}_{5}$ diffraction, two kinds of diffraction patterns. The interplanar distances from the first one are $d_{1}=9.7 \AA$ and $d_{2}=25.0 \AA$. The patterns of the second kind indicate a superstructure (Fig. 8). All the microcrystals are very thin plates oriented normal to the 
Fig. 8. Diffraction pattern of a microcrystal of the reduced electrode XIII.

beam direction; recording of diffraction patterns suitable for the determination of the interplanar distance for the "third direction" was therefore not possible. We did not succeed in performing a reliable analysis confirming the presence of $\mathrm{Mg}$ within the grains exhibiting the superstructure.

The electrode XIV consists of four phases: one with the unit cell of $\mathrm{V}_{2} \mathrm{O}_{5}$, carbon black, PTFE, and a new phase structurally related to $\mathrm{V}_{2} \mathrm{O}_{5}$. The change of the structure of the products of electrochemical cycling with the number of cycles (note the observed difference between the electrodes XIII and XIV) was discussed also in [19] for electrochemically inserted $\mathrm{Li}_{x} \mathrm{~V}_{2} \mathrm{O}_{5}$.

\subsection{Electrochemical $\mathrm{Mg}^{2+}$ insertion in the $\mathrm{V}_{2} \mathrm{O}_{5}$ single crystal II}

The $\mathrm{V}_{2} \mathrm{O}_{5}$ single crystals (II) lost the single crystallinity after the electrochemical $\mathrm{Mg}^{2+}$ insertion. An optical micrograph of the crystal VIII showed broad lines and shadows of the dark $\mathrm{Mg}_{x} \mathrm{~V}_{2} \mathrm{O}_{5}$ within the orange-yellow $\mathrm{V}_{2} \mathrm{O}_{5}$ crystal. Obviously, the insertion process is very nonuniform. The EDX analysis did not indicate the presence of $\mathrm{Mg}$. Thus, the amount of $\mathrm{Mg}^{2+}$ inserted in the single crystals was rather low. The chemical insertion of $\mathrm{Mg}^{2+}$ in the $\mathrm{V}_{2} \mathrm{O}_{5}$ single crystal resulted in no apparent colour change.

\section{Conclusions}

The chemical and the electrochemical $\mathrm{Mg}^{2+}$ insertion in $\mathrm{V}_{2} \mathrm{O}_{5}$ seems to produce similar $\mathrm{V}_{2} \mathrm{O}_{5}$-related phases. But the electrochemical reduction of 
$\mathrm{V}_{2} \mathrm{O}_{5}$ in PTFE-bonded electrodes is more complex and rather nonuniform. At least two new phases (both possibly $\mathrm{Mg}_{x} \mathrm{~V}_{2} \mathrm{O}_{5}$ phases) are formed during the reversible reduction of $\mathrm{V}_{2} \mathrm{O}_{5}$ in wet acetonitrile containing $\mathrm{Mg}\left(\mathrm{ClO}_{4}\right)_{2}$. The presence of one of the new phases in the electrode decreases during electrochemical cycling. Upon reoxidation, the original $\mathrm{V}_{2} \mathrm{O}_{5}$ structure of the $\mathrm{Mg}_{x} \mathrm{~V}_{2} \mathrm{O}_{5}$ phases appears to be restored. In the hydrated sodium vanadium bronzes, $\mathrm{NaV}_{3} \mathrm{O}_{8}\left(\mathrm{H}_{2} \mathrm{O}\right)_{y}$, two layered phases with different water content coexist. The phase $\mathrm{NaV}_{3} \mathrm{O}_{8}\left(\mathrm{H}_{2} \mathrm{O}\right)_{1.5}$ is electrochemically the most active one, which allows $\mathrm{Mg}^{2+}$ insertion from rigorously dry electrolytes. Dehydration occurring above $100^{\circ} \mathrm{C}$ causes a decrease of the interlayer separations as well as a decrease in the coulombic capacity of the bronze, so the preparation and drying of the bronzes below $100^{\circ} \mathrm{C}$ is recommended.

\section{Acknowledgements}

We thank Dr. O. Haas, PSI, for many stimulating discussions. We are also indebted to Dr. K. Kato of the National Institute of Inorganic Materials, Tsukuba, Japan, for the donation of the $\mathrm{V}_{2} \mathrm{O}_{5}$ single crystals, $\mathrm{R}$. Wessicken, ETH, for STEM measurements, H. Meyer zu Altenschildesche, ETH, for NMR measurements, F. Ried, ETH, for EPMA study, and W. Scheifele, PSI, for technical assistance. This work was supported by the Swiss "Bundesamt für Energiewirtschaft" (Grant No. EF-PROCC(91)018).

\section{References}

1. T. D. Gregory, R. J. Hoffman and R. C. Winterton, J. Electrochem. Soc. 137 (1990) 775 .

2. R. J. Hoffman, R. C. Winterton and T. D. Gregory, US Pat. 4,894,302 (1990).

3. P. Novák and J. Desilvestro, J. Electrochem. Soc. 140 (1993) 140.

4. P. Novák, W. Scheifele and O. Haas, Molten Salt Forum 1-2 (1993/94) 389.

5. J. Galy and M. Pouchard, Bull. Soc. Chim. France (1967) 261.

6. J. Galy, M. Pouchard, A. Casalot and P. Hagenmuller, Bull. Soc. Fr. Mineral. Cristallogr. 90 (1967) 544.

7. R. Schöllhorn and H. Meyer, Mat. Res. Bull. 9 (1974) 1237.

8. R. Schöllhorn and W. Schmucker, Z. Naturforsch. 30b (1975) 975.

9. A. Lerf and R. Schöllhorn, Inorg. Chem. 16 (1977) 2950.

10. J. P. Pereira-Ramos, R. Messina and J. Perichon, J. Electroanal. Chem. 218 (1987) 241.

11. P. G. Bruce, F. Krok, J. Nowinski, V. C. Gibson and K. Tavakkoli, J. Mater. Chem. 1 (1991) 705.

12. P. Lightfoot, F. Krok, J. L. Nowinski and P. G. Bruce, J. Mater. Chem. 2 (1992) 139.

13. P. G. Bruce, F. Krok, P. Lightfoot, J. L. Nowinski and V. C. Gibson, Solid State Ionics 53-56 (1992) 351.

14. R. E. Dueber, J. M. Fleetwood and P. G. Dickens, Solid State Ionics 50 (1992) 329.

15. F. Joho, P. Novák, O. Haas and R. Nesper, Chimia 47 (1993) 288. 
16. K. Kato, personal communication, June 1992.

17. R. Gutmann, J. Hulliger and E. Reusser, J. Cryst. Growth 126 (1993) 578.

18. A. D. Weeks, D. R. Ross and R. F. Marvin, Am. Mineral. 48 (1963) 1187.

19. J. M. Cocciantelli, J. P. Doumerc, M. Pouchard, M. Broussely and J. Labat, J. Power Sources 34 (1991) 103.

20. J. A. Jacobson: "Intercalation Reactions of Layered Compounds", in Solid State Chemistry. Compounds (A. K. Cheetham and P. Day, Eds.), p. 217. Clarendon Press, Oxford, (1992).

21. K. Kato and E. Takayama, Acta Crystallogr. B40 (1984) 102.

22. O. P. Lapina, V. M. Mastikhin, A. A. Shubin, V. N. Krasilnikov and K. I. Zamaraev, Prog. Nucl. Magn. Reson. Spectrosc. 24 (1992) 457.

23. H. G. Killian, Kolloid-Z. 185 (1962) 13.

24. N. Baffier, L. Znaidi and J.-C. Badot, J. Chem. Soc. Faraday Trans. 86 (1990) 2623.

25. J. C. Bouloux, I. Milosevic and J. Galy, J. Solid State Chem. 16 (1976) 393.

26. H. G. Bachmann, F. R. Ahmed and W. H. Barnes, Z. Kristallogr. 115 (1961) 110.

27. S. Hub, A. Tranchant and R. Messina, Electrochim. Acta 33 (1988) 997.

28. D. W. Murphy, P. A. Christian, F. J. DiSalvo and J. V. Waszczak, Inorg. Chem. 18 (1979) 2800. 